\title{
The Hoarding in Islamic Marketing
}

\author{
Dr. Abdul Hai Madni \\ Associate professor, Humanities Department, NEDUET, Karachi, Pakistan
}

\begin{abstract}
The needs of every individual living in a society is connected to each other and also implies that no one can live an alone life. Some people have basic requirements related to others or to politics or finance.Therefore trade, industry and agriculture hold a primary and fundamental position in this perspective. Islamic guidance is mentioned in details with some rules and regulations has a great benefit that it is very flexible with every changing era and is adjustable in its own place.

Is hoarding and monopoly prohibited completely or it can be made use of in some cases?

Here are some opinions regarding different Islamic schools of thought.

Therefore it is quite evident that Islamic laws regarding business, industry and profession are devised for the success and welfare of the society because a society very much depends and is in need of such people who are not fatal for the society itself.

Islamic law has never laid down limits regarding one's profit in business, industry or profession and left on the basis of local trends and traditions and its connection with the currency yet it should be within moral values Otherwise would have been fatal for the society.

Keywords:

- Hoarding

- Monopoly

- Provisions

- Conditions

- Prohibition

- examples

- Capitalism
\end{abstract}

\section{Introduction:}

The basic definition of industry and business is that the people living in that society must be benefited with it and to provide the basic necessities of life whether it is related to food or drink, living or beauty, thus it should provide each and every necessity that a human needs.

It is because collection of each individual makes up a society, that is, every individual makes up a society. Therefore needs of every individual living in a society is connected to each other and this also implies that no one can live an alone life. And within these needs some people have basic requirements related to it, some are related to politics and some are with finance.

A person can be depending on someone else for his needs and at the same time someone else might be depending on him for their needs. Therefore trade, industry and agriculture hold a primary and fundamental position in this perspective. Islam is a complete religion which guides its believers in all the aspects of life. This guidance is mentioned in detail in some places and in others it is mentioned with some rules and regulations. The guidance that is mentioned with rules and regulations has a great benefit that it is very flexible with every changing era and is adjustable in its own place.

If human beings as a whole will not accept this guidance in their lives than a direct loss that they will suffer from is that those societies will diminish and personal interest and benefits will be considered more important. And of all rules laid down in this guidance, one of them is related to monopoly and hoarding which is strictly forbidden in Islam, especially at the time when people in a society are made to suffer from it and when people are in need of it too. In such a situation, not to provide people their basic needs, instead storing them and collecting them is nothing but to cherish one's own personal gains.

Is hoarding and monopoly prohibited completely or it can be made use of in some cases?

Here are some opinions regarding different schools of thought:

According to some, business and industries are something that is completely limited within the government regulations and only government bodies can decide that in what aspects it could be dealt accordingly. And that all the business policies will lie under the government main policies as it is found in communism. 
And according to others, government can advice an outline regarding their policies, and then it is up to the businessman and industrialist to manipulate their business needs according to the situation.

Like people who are in favor of capitalism and freedom in economic planning say that.

In both of these schools of thought some affairs are related to Positives and some are related to downsides.

And Islamic point of view regarding finance is a moderate one that is, actually industrialists and businessmen have freedom of behavior and hurriyat but this freedom is not complete freedom in fact it has some limitations. And to abide by them is compulsory. These limitations are basically for the good and interests of human beings so that they could be benefited through it. When the Islamic point of view on business is observed, we see that its biggest and initial feature is to provide profitable affairs to the Islamic society and to prevent it from fatal aspects. And no industrialist or businessmen is allowed to go beyond these limitations.

Therefore it is quite evident that Islamic laws regarding business, industry and profession are devised for the success and welfare of the society because a society very much depends and is in need of such people who are not fatal for the society itself.

In this regard the character of a truthful businessman is more important because he is the biggest source of success and welfare of the society that is why Messenger Allah said: A businessmen who is truthful and trustworthy, at the Day of Judgment he will be in the company of Prophets, Veracious and Martyr.(1)

Islamic law has never laid down limits regarding one's profit in business, industry or profession. InfectIslam has left the profit on the basis of local trends and traditions and its connection with the currency. But still it emphasizes that although there is no limits set on the profit earned, yet it should be within moral values. It is because if there would have been limits on the profit earned then all the businessmen, industrialist and professionalism would have adopted the ways and behaviors of inflation, without discriminating between halaal and haraam. This would have been fatal for the society. That is the reason that there is no limit set on it but at the same time Islam motivates a businessmen to not only focus on the timely benefit that he will get in earning profit but to also keep in mind the reward in hereafter in dealing such affairs.

Those who make extravagant profits are told in the best possible way that in the everlasting life has to give an account of all the affairs he's been doing in this world. And to stop and store the goods and not allowing them to be in the market especially at the time when it is needed then the government of that time should be responsible enough to fix the prices of such goods and also to make sure that no one earns extra profit out of it. Lots of books have already been written in this regard and we tried to present the matter of these massive books briefly which is a need of a Muslim at every step. Therefore we have arranged this topic into 6 points which are as below:

1) The dictionary meaning of hoarding.

2) Order of hoarding under Islamic law which is explained in text and according to the sayings of the scholars and what are its exceptions in case of it being forbidden.

3) Those commodities are discussed which may contain hoarding

4) The conditions of hoarding which are extracted with evidence.

5) Negative impacts of hoarding on the society.

6) How government in command will deal with the prohibitions ofHoarding and its details.

1. Meaningofhoarding

\subsection{According To Dictionary:}

The word hoarding is derived from the Arabic word $ح$ that means greediness, doing wrong, collection (2). And in terms of food it means to buy it and then store it or to collect it so that once there is shortage of it in the market then its price could be raised (3).

Or to collect it and cease it and then wait for its prices to be raised.

Or to stop the goods hoping that would increase its price. (4)

Thus only through its dictionary meaning we can easily observe that it is a collection of two features: greediness and increase in possession.

One aspect should be very clear that a person who collects goods but has no such intention to earn profit through it but instead he intends to help others through it will not lie under the above mentioned category.

\subsection{According To Terminology:}

According to the jurists the definition of this terminology is close to its dictionary meaningOnly Shawafe had explained it in the following way:To buy food items when they are expensive then to store them so that their price rises even more and then to sell those to earn extra profit (5)

And Ahnaf had explained it in the following way:To buy food items and things related to it, then to store them until they get expensive. (6) 
According to Hanblah to buy food items and to store them with themselves in a way that it gets difficult for a common man to buy it, then to wait until it gets more expensive. (7)

Therefore according to all the explanations it is to store items and wait for it to get expensive.

We can explain the summary of all this in the following way that:

1- To buy food items and then to store them, to make it out of reach of a common man such that he cannot buy it and to create shortage of that product in the market so that the prices of such goods or items are increased in that city or country.

2- Hoarding Means to stop goods and to store them which are a basic necessity of common people, may it be related to any food item or anything else, whatever it be it is causing harm to the people. Therefore it could be food products or medicines or clothes or buildings etc and similarly business and other professions when people are in need of it.

3- Regarding hoarding there is no difference in this order that to buy goods from some other place and then to store it or is bought as a whole and then is kept unless its price increases or someone else had made that thing himself.

4- The main reason for the prohibition of hoarding is because of the need of that good is felt that is everything that is stopped and stored will not let under the category of hoarding. Infecthoarding is related to such goods and products which are needed in a society by the people. Therefore if that thing stored is not amongst the things that are not needed by the people then it would not be categorized as hoarding and in such a case storing anything is optional because in such cases it up to the owner to store it or sell it according to his needs.

\section{Provisions of Hoarding in Islamic Shariah:}

Jurists have a difference in opinion regarding the issue of hoarding

Therefore we can find two sayings defining this, one is regarding its prohibition and the other one is regarding its hatred.

First opinion: Hoarding is prohibited

Many of the scholars agreed with this opinion including Ahnaf, Maliki, Shawafe, and Hanblah. Most of the scholars amongst them and the scholars of Zawahir all of them belong to the same school of thought. (8) Their evidences are as follows:

\subsection{From Quran:}

1- ALLAH says: Verily those who disbelieved and hinder from the path of Allah, and from AL masjid AL illgotten which we have made open to all, the dweller in it and the visitor from the country, and pilgrimage, and whoever inclines to evil actions therein or to do wrong, we shall cause to taste from a painful torment. (9)

Qurtubi in his tafseer of this ayah has taken a narrationwhich imam abu daud in his sunan in which Abu Yale bin Umyah explains:"Hoarding of food in Ill-gotten is atheism in it." (10) (11)

And regarding the prohibition of hoarding there are manyhadiths.

\subsection{From Hadith:}

2- Maumar bin Abdullah explains the saying of Prophet (s.a.w):"No body hoards except the wrongdoer." (12)

3- Messenger of Allah(s.a.w)says:"The boisterous is prosperous and hoarder is cursed." (13)

4- Prophet(s.a.w) says:Whoever monopolizes to exaggerate for Muslims he is wrongdoer and he is acquitted from protection by Allah. (14)

Famous Islamic scholar Shoukani says:There is no doubt that the Hadiths of this chapter end collectively to deduce the inadmissibility of monopoly, If we assume there is no proof of anything right, so how and Hadith of Muammar mentioned in Sahih Muslim and authorizing that monopolist wrong enough to benefit non-passport, because the wrong is the guilty and sinner (15).

Argument on the prohibition of hoarding depends on reasoning that is to keep harmful things away from a reach of a common man like all the scholars agrees that if anyone has food goods and people are in need of it and they cannot find any alternative then in such a case that person having food goods will be forced sell it so that people should fulfill their needs And to prevent the sale which revoked the right people and narrowing it to them, leads to damage them.

Second Opinion:Hoarding is abhorrent

According to some of the shawaafay(16) although it is proved that related to the food items even shawafe consider Hoarding to be ill-gotten. (17)

The Correct opinion of scholars from different schools of thought and their reasons: 
1) Above text for the prohibition of hoarding is more firm in context with its stature in which those who store goods are been warned of it very strictly and the thing that is been stored is also not discriminated that is it could be anything.

2) According to the Islamic shariahregarding hoardingthe main and core law is to put an end to the evildoers and to solve the problems of a society.

3) The immediate reaction of hoardingis that the prices of goods are increased which is harmful for a society.

Muslim had explained a Hadith of the Prophet (s.a.w):"Anyone who practiced hoarding will be sinful"

Nawawi explains this:Prophet (s.a.w) said:"anyone who practiced hoarding will be sinful". And a second narration which says: "those who are sinful they practice hoarding".

This hadith is clear evidence that in Islam hoarding is considered ill-gotten which means hoarding of things which are useful in daily life routines. That is if someone buys the food items at low price and then do not sells it with the intention that he will sell it when its prices are raised so that he can earn excessive profit. But things other than those which are used in daily life can be stored and collected and will not be considered illgotten. All the scholars agree that if anyone has a collection of food goods which he has stored and if the people living there are facing problems regarding food. Then the government has got the right to compel that person to sell his food goods so that the problems of the public can be dealt.

In situation where hoarding can be considered as exception are as follows:

1) Those things which if someone has stored for a limited time to invest or fulfill his personal use only on a condition that this storing is not a source of harm for the normal public and also that there is no increase in the process.

2) Government also collects many goods for the public in cases of emergency conditions that is allowed.

3) Those who buy food goods when its prices are cheap and then use it for his own use.

4) And those who stores wheat etc produced in a year.

\subsection{In which affairs hoarding is done:}

In the economic system of Islam there is a lot of importance on the fact that nothing should be done that is against the nature or a natural process.: that is why hoarding is prohibited because in doing it there are different variations in the prices of the goods, these days the need of a certain products is created through advertising which also according to the Islamic point of view is incorrect. Therefore Prophet(s.a.w) has ordered never to lie and cheat in a business and also not to present the goods of their product in an exaggerated manner. And to hide its defects is also considered to be a lie. This is commonly done these days in advertising.

But of all these the most harmful is hoarding and to store things in such a manner that not only causes harm to a people but to the whole society. That is why I first explained its causes because it brings harm $\mathrm{n}$ evil to the society where everyone then will start to live for their own self.

Hoarding as explained above is when goods are stored with the intention that its price when increased will be a source of excess profit, may it be from food goods or from the goods which are of daily use for people. Therefore it includes nutritious items, medicines, clothes, land and houses $\mathrm{n}$ property etc.

In fact it includes every kind of business, services related to administration and management. Means it includes all those things which a society is in need of and because of any reason it has been stopped or been collected in few hands.

When all of this issue is very clear now then we can easily say that it includes every such thing that any businessmen or any profit earner does it for their personal interest and profit, and collects and stores it so that when the prices of those items or goods will rise he will sell it to earn excess profit.

But some Juristshave assessed that only suchthings stored will be considered in this category. A brief explanation of which is as follows:

First opinion and its proofs:

Only those goods which are related to food and drinks, collection of such goods are ill-gotten. This is according to the shawafe and hanblah. (18)

Some have arguments regarding this first opinion that hoarding is only limited to things because sunnat, asaar and intellect proves it.

As far as sunnat is concerned, saiyyadna Umar bin Khattab said that Prophet(s.a.w) said:

"Whoever hoards food of Muslims Allah will beat him with leprosy and bankruptcy" (19)

The argument is given regarding this Hadith as written by Shaukani that the authenticity of Hadith-e-Umar ibne Hatham has been discussed over by scholars. Abu Daud has written that this Hadith rejecter narrates, Hafiz Zahbi says: this is the same Hadith which is narrated by Imam ibne maja and its authenticity is Abu Yahya Almaliki. (20) 
Similarly there is another Hadith narrated by Abdullah bin Umar:"Whoever hoards food for forty days so he will be acquitted of Allah (21)

And this Hadith is zaeef(unauthenticated) (22)

This makes it clear that hoarding can be practiced on other then food and drinks items as well because if hoarding except food and drinks was prohibited/ Ill-gotten then these people wouldn't have done that and wouldn't have given fatwas on it.

Second opinion and its proofs:

Hoarding is not related to any particular thing infact it's a common term means it relates all those things which a man is In need of and is not available to him so much so that its price is raised to an extent that he is unable to buy it. This is according to the Maaliki, (23)Ahl-zaahir, (24) and amongst Ahnaaf from Abu Yusuf,

(25)Shaukaani(26) andal-Sana'ani. (27)

Regarding second opinion some has arguments on the matter of the Hadith that is they have not discriminated between the food and drinks of humans and the food and drinks of other creatures beside humans.

As in Sahih Muslim there is a Hadith narrated by Sees bin Almaseeb in which Prophet(s.a.w) said: whosoever practices hoarding is sinful. (28)

Similarly Maqal bin Yasaar says that the Prophet (s.a.w) said:

"Whoever hoards food to raise the prices for Muslims Allah will put him in fire." (29)

Third opinion and its proofs:

Hoarding is limited to human's meal or food items. And this opinion is according to some of the Jurists amongst Hanblah. (30)

Those who supports this opinion has given arguments that hoarding is only related to food and drinking items because overall usually harm is caused in a society due to the goods related to food and drinks and shortage of such goods can affect the whole society.

As Kasani said: harmfulness is usually related to the foods of humans and animals therefore hoarding meaning are only limited to their eatables. (31)

An objection can also be done on this that harm is possible even with things other than eatables of humans and animals. For example in wars, hoarding of weapons and medicines can also lie in this category.

\subsection{Predominant:}

When these sayings are judged with respect to the evidence given then we can sort out that imam Malik (may Allah have mercy on him) and imam Yusuf (may Allah have mercy on him) opinion is more appropriate because in most of the hadiths there is no bounding or limitations that only particular/specific goods storing is not allowed and for the rest of them its permissible. In fact it is a general rule that must be applied on all the products and goods.

And if we need reasoning than even that too compels us to agree that it should not be a specific good infect it should be kept general. And anything that contains reasons should be containing the orders made for hoardingbecause order always remains with reasons.

\section{Conditions for Prohibition Of Hoarding:}

There is agreement amongst the scholars that hoarding does not only means to cease something because it can be possible that a person can might store food items for himself and his family for a year or for a limited period of time like we observe that in people who lives in villages. They store wheat for an year and that is meant to serve their own personal needs therefore it could not be included in hoarding As Imam Bukhari ibn Shahab Zubari has narrated that Syed Umar said that Prophet (s.a.w) said:

"Banu Nadheer used to sale out the dates and confine it for a year. (32)

In this Hadith it is quite evident that to cease food items and to store them is halaal and optional and does not lie in the category of hoarding therefore not ill-gotten. And this hadith also doesn't contain any evidence that goods cannot be collected or stored more than a year.

Considering this we can say that hoarding is ill-gotten when it fulfills all its conditions which fuqaha has explained and our as follows:

Goods that are stored must belong to foods or drinks

We have already explained the opinions of jurists and their evidence in this regard and prohibition on hoarding will be done on those things which are humans need because they explained Hadith talks in general and does not contain any specification.

Goods that are stored must be done from a local market.

If that thing is bought from somewhere else or product from domain of hoardercan't be considered in prohibited hoarding due to two reasons. 
Hadith: "The boisterous is prosperous and hoarder is cursed." (33)

The public's right could be suspended if the good was bought from the inside, so its purchasing and hoarding could harm the public but if the good was bought and brought from abroad then there is no such right, because Buyer who bought and hoarded was not supposedbasically, although it was better for him to ignore hoardingas it is harmful for people

The goods that are collected and bought at that time when they were very few in the market and its prices were very high and for him to buy such a thing and then storing it, both are harmful for the people.

Whereas some hadiths that contain prohibition of hoarding they also contain the time period for it andthat is 40 days as it is found in a Hadith of Umar explains

"Whoever hoarded foodforty dayswasacquitted ofGodandGodacquittedhim.(34)

And this Hadith is considered to be Zaeef as it has been already told.

Thus here a question arises that the time period given in this hadith regarding hoarding. Can it be considered as one of its condition or not?

We have four sayings of fuqaha concerning this matter:

1) Minimum time period required to be called as hoarding is 40 days found in hadith Umar.

2) At least one month should be the time period because more than that would be hastiness.

3) Hoarding has nothing to do with any fixed term or time period because matter that is contained in the hadith is not the time period infect it's a perspective that is explained there. It could be something that causes harm.

And Shaukani writes I couldn't find a single faqih who would trust on the time period used for the prohibition of hoarding. (35)

4) Hoarding can be sinful with the kind of act it is and how much harm and loss it has caused to the society and the people living there irrespective of the time period or term defined for it. Therefore setting a term for it is not sensible.

2. Effects of hoarding on the society:

1) If we look around the society we can deduce the fact that hoarding is practiced and found in differentways, economically, politically and collectively it is dispersed in our society. And in reality it is something that is spreading evil in the land which Allah (SWT) has also mentioned in his final revelation. (36)

2) Prophet(s.a.w) has also warned the ummah from doing such acts and has strictly prohibited them from committing it because this is as told above something equivalent to spread evil in the society.

3) Islamic think tank and economist says that practicing hoarding is against the economic rights of the people and due to that resources gets limited because in doing it we alsoof against Allah and His Messenger (s.a.w). And it creates difficulties for the people and their rights are exploited. And to take people's money in an illegal and improper way. These entirethings are categorized as wrong doings which eliminates the barakah in any work. And because many new economic systems that are being introduced in recent time has also created many new ways of practicing hoarding as the government that supports socialism system, it gives rise to this evil. Similarly those who support capitalism system, they also are responsible in giving rise to this evil.

4) And in both these situation the result is always been the same that is the people and society both suffers from injustice and tyranny which keeps on increasing if this practice in continued. This can be explained in points as follows:

5) People are deprived of their economic freedom that is they cannot buy things in the market according to their needs and wishes and whatever is available to them may it be at a high price and not meeting their standards yet they are compelled to take them only. Especially when that thing is of their daily use.

In such conditions, doors to business opportunities for the people also get closed because in the market only few people have absolute monopoly.

Sometimes it has also been witnessed that people practice hoarding so that the particular product does not get in excess in the market which might result in a decrease of its price. And sometimes the excess quantity is destroyed so that the decrease in price can be prevented.

Hoarding causes a destruction of a fair economic balance in the society and the most who are affected from it are the customers because economic balance is basically done to provide relief to the common people (customers). 
Hoarding also results in only old goods to be available in the market and new products/goods are prevented to be introduced in the market because hoarding is a cause for its prevention.

Therefore such negative effects that a society experiences can lead to such an extent that can even result in direct barbarism, murder and vandalism. And the most important thing is that it is against the orders of Allah: "Go Thou to Pharaoh, for He has indeed transgressed all bounds." (37)

Countering absolute monopoly, its ways and some contemporary tips:

A capitalist system does not give people the due return of their efforts and hard work and socialism ceases their freedom, it cannot bear the concept of selfness and freedom and tries to chain them up in their own concepts. In such difficult conditions if we can find the only ray of hope is in the system of life that was brought by the last and final messenger (s.a.w) which we know by the name of Islam.

Prophet Muhammad (s.a.w) said:Search for halal earning is compulsory on every Muslim. (38)

These Hadith makes it very clear that Islam has never stopped its followers to earn in a halal way in fact it encourages and considers it something prestigious and honorable to make efforts in earning halal. But it does not allow illegal earning and makes a person accountable in their earning to be considered it as permissible. And all those sources of economic growth are considered as ill-gotten, illegal non permissible in which other people rights, their needs ,their helplessness and their inexperience is used to earn profit or by if by deceiving someone his money is been grabbed. All these sources are prohibited in the sharia and are against the laws, which include interest, gambling, hoarding, bribe, black marketing and every kind of wrong source is considered ill-gotten in Islam. Money that is earned through these sources is not acceptable in the court of Allah even if it is spending in the way Allah.

Reformation in Islam begins from the very basics therefore the present ruler is held responsible and has got the golden opportunity to set things and his intentions aright because this is the way through which businessmen can be made to follow the sharia rules and this is how practices like hoarding can be countered.

A brief explanation is as follows:

Islam from the very beginning teaches these things to its believers and guides them in such a way that he never goes through such a situation in which he makes use of other peoples respect and values to earn money. All those sources due to which money is collected in one hand or in the hands of specific community in a society. Islam has closed all these doors forever. Those countries running on capitalism are sucking the blood of their own nationals and the bones of needy are been eaten there. If we observe their condition with an unbiased eye then you can easily deduce that result. This illegal and unjust distribution of wealth is because of these wrong resources used for earning which Islam declares as ill-gotten.

Those nations and nationals who believe in the Islamic economic system for the distribution of wealth and doesn't even think of earning anything which is declared ill-gotten in Islam. In such places this unjust distribution is not found.

According To consideration of the Islamic Law that the Allah and His Prophet the supreme authority in each and every affair can only lead us to peace and prosperity and whoever turns away from it will face the worst reactions.

And Prophet(s.a.w) said: 'I I am leaving behind two things for you if you hold these things firmly you will never be misguided, firstly Quran Majeed and secondly my Sunnah ' (40)

A very strict watch must be kept by the government and regular check and balance must be kept of the market that no illegal activity is happening in any corner that is causing harm to the common people and is against the sharia rules of Islam.

To run such an administration, government should hire such individuals who are truthful and trustworthy and do not indulges themselves in such heinous crimes because accountability in Islamic system can be successful if the individual who are responsible for doing accountability themselves are true believers.

Ibn e Tahmiya writes: hoarding that is done deliberately to create a shortage of any basic product used by the common people such that it is stored and then waited for its price to be raised to earn extra profit will be considered a wrongdoer. Therefore it is compulsory on the government to force him and make him sell his stored products to fulfill needs of the people.

Being successful in the action taken against those who practice heading is very essential because if it doesn't happen then even other people get a chance to be involved in such a heinous crime. Islam is the only way of life that not only prevents from all sorts of evil but in fact it even closes all the ways heading towards those roads. (41)

Concluding remarks:

The important points that can be marked out of all this discussion are: 
1) Hoardingis a very huge economic crime which is absolutely against the principles of Islam and it has different ways in which it is practiced and knowing all of them is very important.

2) Basically is related to food goods infact every such goods which is used by people in their daily life. Therefore prohibition on hoarding is agreed upon decision in which no one has a difference in opinion.

3) Whatsoever goods are taken in storage doesn't make a difference whether it be manufactured by the hoarder himself or whether he has bought it or has got it from somewhere outside if it is a cause of harm for other people than it will be categorized as.

4) The present government will be held responsible for its accountability and ways to counter it.

\section{Reference:}

[1]. Al-bukhari, Muhammad bin Ismail, Sahih-ul-Bukhari, add: 1981, published: dar-ul-fikr, H: 1970

[2]. Al-jizri, Mubarak bin Muhammad, al-nihaya fi ghareeb-il-hadith, add: 1979, published: almaktab-tul-ilmiyyah, berut, V:1, P:418

[3]. Ibn-e-Manzoor, jamal-ud-din Muhammad, lisaan-ul-arab, add: 1985, qum, iran, V:3, P:267

[4]. Al-raazi, Hamza bin shahab-ud-din, mukhtar-us-sihaah, add:1994, published: dar-ul-kutub-ul-ilmiyyah, berut, V:2, P:635

[5]. Al-ramali, Muhammad bin abu-ul-abbas, nihaya-tul-muhtaajilasharh-ul-minhaaj, add: 2003, published: dar-ul-kutub-ul-ilmiyyah, berut, V:3, P:472

[6]. Ibn-e-aabdeen, Muhammad amen, Hashiyyatoradd-ul-Muhtaaraladurar-ul-mukhtar, add: 1995, published: dar-ul-fikr, berut, V:6, $\mathrm{P}: 398$

[7]. Al-maqdasi, Abdullah bin ahmed, al-mughni fi fiqh-il-imam ahmed, add:1985, published: dar-ul-fikr, berut, V:3, P:283

[8]. Al-sharbeeni, muhamma, Mughni al-muhtaajilamarifa-tu-ma'anialfaz-ul-minhaj, add: 1980, published: dar-ul-fikr, berut, V:2, P:51

[9]. Al-Quran ch:22, ver:25

[10]. Al-Qurtubi, Muhammad bin Ahmed, Al-jamay o li-ahkam-ul-quran, add: 2003, published: daralam-ul-kutub, al-riyadh, V:12, P:26

[11]. Abu Daood, sulaiman bin ash 'as, SunanAbiDaood, add:2000, published: dar-ul-kitab-ul-arabi, berut, H:2022

[12]. Muslim bin Hujjaj, Sahih Muslim, Add: 2001, Published: Dar ihyaa-ut-turaas-al-arabi, berut, H:1605

[13]. Al-Qazveeni, Muhammad bin yazeed, sunanibn-e-maajah, Add: 1999, published: Dar-ul-fikr, Berut, H:2153

[14]. Ahmed bin Hanbal, Al-Musnad, Add:1997, published: Mo'assisah-tu-rislah, Berut, H:8602

[15]. Al-shaukaani, Muhammad bin ali, Nail-ul-Autaar, Add:1973, published: Dar-ul-fikr, Berut, V:5, P:278

[16]. Al-nowavi, Muhy-ud-din bin Sharaf, Al-majmoosharh-ul-muhazzab, Add: 2002, Published: Dar-ul-kutub-ul-ilmiyyah, Add:2002, published: dar-ul-kitab-ul-arabi, berut, V:13, P:44

[17]. As per Ref:16, V:13, P:44

[18]. As per Ref:17

[19]. As per Ref: 13, H:2155

[20]. As per Ref: 15, V:9, P:458

[21]. Al-Hakim, Muhammad bin Abdullah, Al-MustadrakalaSahihain, Add: 1990, Published: dar-ul-kitab-ul-arabi, berut, H: 2165

[22]. Albaani, Nasir-ud-din, Ghayat-ul-Maram fi takhreejAhadeeth al-Halamwa al-Haram, Add:1985, Published: AlmaktabulIslami, Berut, P:194

[23]. Al-Qurtubi, yousaf bin Abdullah, al-Kafi fi fiqhAhl-ul-madina, Add: 1980, published: Maktab-ul-riyadh, V:2, P:730

[24]. Ibn-e-Hazm, Ali bin Ahmed, Al-muhallah, Add: 1983, published: Dar-ul-Afaaq al-jadeeda,berut, V:4, P:184

[25]. Al-Kasaani, ala-ud-din, Badai-us-sanai fi tarteeb-is-sharai, Add: 1986, published: dar-ul-kitab-ul-arabi, berut, V:11, P: 23

[26]. As per Ref: 15, V:8, P:496

[27]. Al-San'aani, Muhammad bin Ismail, Subul-us-Salaam, Add: 2005, published: dar-ul-kitab-ul-arabi, berut, V:4, P: 130

[28]. As per Ref:7, H:1605

[29]. As per Ref: 13, ch:5, H:60

[30]. As per Ref:7, V:10, P: 401

[31]. As per Ref: V:11, P:25

[32]. As per Ref:1, H:5357

[33]. As per Ref: V:11, P:25

[34]. As per Ref:21, H:2165

[35]. As per Ref:15, V:9, P: 461

[36]. Al-Quran ch:30, V:41

[37]. Al-Quran ch:20, V:123-124

[38]. Al-behaqqi, Ahmed bin hussain, Sunan-ul-Kubra, Add:2003, Published: Dar-ul-kutub-ilmiyyah, Berut, H:13414

[39]. As per Ref: 21, H: 319

[40]. Ibn-e-taimiyyah, Abdul Haleem, Al-Hisbah fi Islam, Add:2001, Published: dar-ul-fikr, berut, P:12 